\title{
Stem and leaf anatomy of Plectranthus neochilus Schltr., Lamiaceae
}

\author{
Márcia do Rocio Duarte*, Juliano Ferreira Lopes \\ Laboratório de Farmacognosia, Departamento de Farmácia, Universidade Federal do Paraná, \\ Av. Pref. Lothário Meissner 632, 80210-170, Curitiba, PR, Brazil
}

\begin{abstract}
RESUMO: "Anatomia caulinar e foliar de Plectranthus neochilus Schltr., Lamiaceae". Plectranthus neochilus Schltr. é uma erva aromática denominada boldo ou "boldo-gambá" e empregada no tratamento de insuficiência hepática e dispepsia na medicina popular. Este trabalho investigou a anatomia caulinar e foliar, com a finalidade de contribuir na identificação dessa planta medicinal. O material botânico foi preparado de acordo com microtécnicas usuais. O caule tem secção transversal quadrangular e, em crescimento secundário no nível analisado, exibe epiderme unisseriada e numerosos tricomas. Os tricomas glandulares são capitados e peltados. Os primeiros têm pedicelo curto e unicelular ou longo e pluricelular e cabeça uni ou bicelular. Os peltados apresentam pedicelo curto e cabeça ovóide com oito células. Os tricomas tectores são pluricelulares, unisseriados e recobertos com cutícula granulosa. Observam-se colênquima angular, câmbio vascular formando floema em direção centrífuga e xilema para o centro, e calotas de fibras perivasculares apostas ao floema. A lâmina foliar tem epiderme uniestratificada revestida por cutícula estriada, estômatos diacíticos em ambas as superfícies, numerosos tricomas similares aos do caule e mesofilo homogêneo. A nervura central possui um ou dois feixes vasculares colaterais e o pecíolo apresenta vários feixes colaterais em arco aberto.
\end{abstract}

Unitermos: Plectranthus neochilus, Lamiaceae, anatomia, boldo-gambá, tricomas.

\begin{abstract}
Plectranthus neochilus Schltr. is an aromatic herb named "boldo" or "boldogambá" and employed for treating hepatic insufficiency and dyspepsia in folk medicine. This paper has investigated its stem and leaf anatomy, in order to contribute for the medicinal plant identification. The botanical material was prepared according to standard microtechniques. The stem has quadrangular transection and, in secondary growth at the level analyzed, shows uniseriate epidermis and numerous trichomes. The glandular ones are capitate and peltate. The former has short unicellular or long multicellular stalk and uni- or bicellular head. The latter presents short stalk and eight-celled ovoid head. The non-glandular trichomes are multicellular, uniseriate and coated with granular cuticle. It is observed angular collenchyma, cambia forming phloem outward and xylem inward, and perivascular fiber caps next to the phloem. The blade has uniseriate epidermis coated with striate cuticle, diacytic stomata on both surfaces, numerous trichomes similar to the stem ones, and homogeneous mesophyll. The midrib shows one or two collateral bundles and the petiole has many of them distributed as an open arc.
\end{abstract}

Keywords: Plectranthus neochilus, Lamiaceae, anatomy, "boldo-gambá”, trichomes.

\section{INTRODUCTION}

The family Lamiaceae Lindl. consists of 258 cosmopolitan genera (Judd et al., 1999), mostly distributed in the Mediterranean region and eastward into Central Asia (Cronquist, 1981). Considered one of the largest genera, Plectranthus L'Hér. includes ornamental (Judd et al., 1999), edible (Temple et al., 1991; Allemann; Hammes, 2003; Allemann et al., 2003) and medicinal species, e.g. Plectranthus amboinicus (Lour.) Spreng. (Ruiz et al., 1996) and Plectranthus barbatus Andrews (Matu; Van Staden, 2003; Pereira et al., 2004; Morais et al., 2005; Tôrres et al., 2005;
Vendruscolo et al., 2005; Silva et al., 2006; Oliveira et al., 2007a).

Among the medicinal species of the genus, Plectranthus neochilus Schltr. is an aromatic herb employed in folk medicine for treating hepatic insufficiency and dyspepsia and commonly called "boldo" or "boldo-gambá" in Brazil. Its fresh leaves have a distinct odour and are taken as infusion or aqueous extract for healing purposes (Lorenzi; Matos, 2002).

Various works have been carried out to identify the chemical constituents of the genus (Vera et al., 1993; Liu; Ruedi, 1996; Ngassoum et al., 2001; Abdel-Mogib 
et al., 2002; Kerntopf et al., 2002; Mendes et al., 2006), and to investigate their antioxidant (Burgi; Ruedi, 1993; Juch; Ruedi, 1997; Narukawa et al., 2001), antimicrobial (Rabe; Van Staden, 1998; Zollo et al., 1998; Mathpal et al., 2002; Rijo et al., 2002; Gaspar-Marques et al., 2006; Oliveira et al., 2007b) and pharmacological properties (Buznego; Perez-Saad, 1999; Cerqueira et al., 2004; Uawonggul et al., 2006). An extensive review of ethnobotanical uses of Plectranthus has been presented by Lukhoba et al. (2006). Since few studies are devoted to the morphological characterization, this paper has investigated the stem and leaf anatomy of P. neochilus (Figure 1), in order to contribute for the medicinal plant identification and for distinguishing it from other species commonly named boldo, such as "boldo-brasileiro" (P. barbatus Andrews), "boldojaponês" (Vernonia condensata Baker, Asteraceae) (Lolis; Milaneze-Gutierre, 2003), and boldo-do-chile (Peumus boldus Molina, Monimiaceae).

\section{MATERIAL AND METHODS}

The botanical material was collected at the Horto de Plantas Medicinais, Departamento de Farmácia, Universidade Federal do Paraná, in CuritibaPR (coordinates of $25^{\circ} 26^{\prime} 45^{\prime} \mathrm{S}$ and $49^{\circ} 14^{\prime} 25^{\prime} \mathrm{W}$, altitude of $930 \mathrm{~m}$ ), in March 2003. The voucher specimen was identified and registered as MBM 219584 in the herbarium at the Museu Botânico Municipal de Curitiba.

Stem fragments cut at $5 \mathrm{~cm}$ from the caulinar apex (approximately at the $6^{\text {th }}$ node) and fully developed leaves were fixed in FAA 50 (Johansen, 1940) and kept in $50 \%$ ethanol solution (Berlyn; Miksche, 1976). The examined foliar region was the lower half of the blade, including the midrib, and the petiole. Transverse and longitudinal freehand sections were stained either with astra blue and basic fuchsine (Roeser, 1972) or toluidine blue (O'Brien et al., 1964). Microchemical reactions were applied with hydrochloric phloroglucin to reveal lignified elements (Sass, 1951), iodine-iodide to starch (Berlyn; Miksche, 1976), Sudan IV to lipophilic substances (Foster, 1949) and ferric chloride to phenolic compounds (Johansen, 1940). The photographs were taken by the light microscope Olympus BX40 attached to the control unit PM20.

\section{RESULTS}

Plectranthus neochilus has a quadrangular stem in transection, and it reveals an incipient secondary growth at the level analyzed (Figure 2). The epidermis is uniseriate (Figure 3), consisting of polygonal cells in shape in front view, being wider tangentially than radially. It remains as the dermal system, although the phellogen has been established (Figure 3). Many glandular and non-glandular trichomes are seen (Figures 3, 5-8). The former varies, being capitate and peltate. The capitate trichomes are numerous and show short unicellular or long multicellular stalk and uni- or bicellular head (Figures 3, 5). The peltate trichomes are scarce and slightly sunken in the caulinar epidermis, presenting short stalk and eight-celled ovoid head (Figure 6). The secretion of glandular trichomes is lipophilic and cuticle detachments can be seen on the head. The non-glandular trichomes (Figure 7) are single, multicellular and uniseriate, consisting of about three to ten cells, with an acute apex and eventually a stalk cell dehydrated. These trichomes are coated with a granular cuticle (Figure 8).

In the cortex, below the phellogen, a continuous strand of collenchyma is found (Figures $2,3)$. It is angular and comprises three or four rows. The multilayered cortical parenchyma has chloroplasts and shows small intercellular spaces. The innermost boundary of the cortex is represented by a single layer of large parenchymatic cells, whose tangential and radial walls are impregnated with lipophilic substances. The vascular cambia form xylem inward and phloem outward, being active mainly in the fascicular region and toward the xylem, although collateral bundles can be distinguished (Figure 2). Caps of perivascular fibers are next to the phloem and all the secondary xylem cells are lignified (Figure 4). The pith consists of thin walled parenchymatic cells, comparatively greater, containing many amyloplasts and forming small intercellular spaces (Figure 2).

The blade, in surface view, has epidermal cells with sinuous contour, more evident on the abaxial surface (Figures 9, 10). In transection, the single-layered epidermis is covered with a thin and striate cuticle. There are glandular and non-glandular trichomes similarly to the stem ones on both surfaces. The epidermal cells which surround the trichome bases (two to eight cells) have slightly polygonal shape and detachment areas are distinguished. Diacytic stomata with unequally sized subsidiary cells occur on the lamina, predominantly on the abaxial side (Figures 9, 10), and they are slightly raised above the other epidermal cells (Figure 11). The inner and outer periclinal cell walls of the guard cells are thicker and the cuticle forms ledges on the outer side.

The chlorenchyma comprises about twelve layers of nearly isodiametric cells, progressively smaller to the abaxial side (Figure 12). Minor collateral bundles are encountered in the middle of the homogeneous mesophyll. They are collateral and encircled by a parenchymatic sheath.

The midrib transection shows a plain-convex shape (Figure 12). Below the uniseriate epidermis is the collenchyma which is angular and consists of about two rows. Embedded in the ground parenchyma, there are one or two collateral vascular bundles (Figures 12, 13). The tracheary elements are distributed orderly in ranks isolated by parenchymatic cells and the phloem is reduced (Figure 14). 
The petiole (Figure 15) has nearly plainconvex contour in transection and the epidermis shows the same characteristics of the blade. A continuous strand of angular collenchyma, formed by two or three rows (Figure 16), encircles the ground parenchyma, in which various vascular bundles are embedded. They are collateral and distributed as an open arc, where the two major bundles are seen in the centre (Figures 15, 17).

\section{DISCUSSION}

The caulinar secondary growth of $P$. neochilus is of the ordinary type, as observed in many herbaceous dicotyledons (Esau, 1977). The rectangular transection is frequently described for Lamiaceae (Metcalfe; Chalk, 1950; Barroso, 1991), as well as the evident collenchyma in the four angles (Cronquist, 1981), which is considered of diagnostic value, according to Metcalfe; Chalk (1950). In the studied species, the stem reveals quadrangular cross-section, however the arrangement of the collenchyma is not restricted to the angles.

The epidermis remaining as the dermal system, despite the formation of the phellogen below it, has been recorded for herbaceous species during early secondary growth (Esau, 1977) and the first phellogen often arises soon after the vascular cambium (Mauseth, 1988). Comparing with the related species $P$. barbatus, commonly called "boldo-brasileiro", the establishment of the phellogen occurs just below the epidermis and it becomes active, producing phellem outward (Scavone, 1965).

As regard as the innermost layer of the cortex whose walls are impregnated with lipophilic substances, Mauseth (1988) has stated that a thin layer of hydrophobic matrix can permeate all primary walls of the endodermis, and the presence of Casparian strips is more characteristic in roots than stems. Accordingly, in P. barbatus stem, the endodermis is not typical and it contains plenty of amyloplasts (Scavone, 1965).

The occurrence of wide interfascicular regions with distinguishable collateral bundles has been mentioned for herbaceous dicotyledons (Esau, 1977). The vascular system organization of $P$. neochilus resembles of P. barbatus (Scavone, 1965) and of the related genus Coleus Lour., whose xylem and phloem are predominantly formed in the fascicular regions (Esau, 1977).

Concerning the leaf anatomy, the family exhibits predominantly diacytic stomata on both surfaces (Metcalfe; Chalk, 1950). Plectranthus neochilus shows this pattern, unlike the reported anomocytic stomata for P. barbatus (Table 1) (Scavone, 1965) or Plectranthus australis R.Br., in which an alternative type has been described. According to Metcalfe and Chalk (1988), this complex is named diallelocytic, consisting of three or more C-shaped cells of graded sizes at the right angles of the guard cells.
Trichomes are considered relevant in comparative systematic investigations and morphodiagnosis (Metcalfe; Chalk, 1988). The occurrence together of diverse kinds of glandular and non-glandular trichomes is characteristic of Lamiaceae (Metcalfe; Chalk, 1950). The peltate trichomes, which have a uniform morphology, as well as the other types of capitate glandular and non-glandular trichomes have been described for the family (Metcalfe; Chalk, 1950; Werker, 1993) and Plectranthus madagascariensis (Pers.) Benth. (Ascensão et al., 1998), Plectranthus ornatus Codd (Ascensão et al., 1999) and P. barbatus (Scavone, 1965). Moreover, based on Ascensão et al. (1999), the peltate trichomes of P. ornatus are confined to the abaxial leaf surface, differing from $P$. madagascariensis (Ascensão et al., 1998) and from the present findings, since these species have exhibited them on both surfaces. As Werker (1993) mentioned, considering a functional viewpoint, glandular trichomes produce essential oils which apparently protect against herbivores and pathogens, as well as attract pollinators in floral parts. Similarly, the histochemical results on the secretion of $P$. ornatus indicate that peltate trichomes produce essential oils, resiniferous acids and flavonoid aglycones, and capitate trichomes also contain polysaccharides (Ascensão et al., 1999).

With reference to the chlorenchyma organization, isobilateral, dorsiventral or centric mesophyll have been frequently reported for Lamiaceae (Metcalfe; Chalk, 1950), as the dorsiventral type mentioned in P. barbatus (Scavone, 1965). Nevertheless, homogeneous mesophyll occurs in P. neochilus (Table 1).

In comparison with other species called boldo which belong to different botanical families (Table 1), there are monographs of boldo-do-chile (Peumus boldus Molina, Monimiaceae) in different pharmacopoeias which describes its leaves as showing deciduous non-glandular trichomes, unicellular and united at a prominent base forming a star-shaped or stellate type, anomocytic stomata found exclusively on the abaxial surface, nearly polygonal epidermal cells in surface view, hypoderm next to the adaxial side, secretory cells distributed in the dorsiventral mesophyll and concave-convex midrib in cross-section ( $\mathrm{Ph}$. Helv. VII, 1991; BHP, 1996; F. Bras. IV, 1996). In addition, Vernonia condensata Baker, Asteraceae, popularly known as "boldo-japonês", has leaves with tetracytic or anomocytic stomata on both epidermal surfaces, twoarmed non-glandular trichomes consisting of various cells in one rank and a T-shaped long apical one, capitate glandular trichomes, multicellular and inserted in an evident depression, prisms and druses of calcium oxalate, dorsiventral mesophyll and a biconvex midrib (Barreto et al., 1994). 
Table 1. Comparative anatomical characters of leaves of species named "boldo": Plectranthus neochilus, Plectranthus barbatus, Peumus boldus and Vernonia condensata.

\begin{tabular}{|c|c|c|c|c|}
\hline $\begin{array}{l}\text { Leaf anatomical } \\
\text { characters }\end{array}$ & P. neochilus & $\begin{array}{l}\text { P. barbatus } \\
\text { (Scavone, 1965) }\end{array}$ & $\begin{array}{l}\text { P. boldus } \\
\text { (F. Bras IV) }\end{array}$ & $\begin{array}{l}\text { V. condensata } \\
\text { (Barreto et al., 1994) }\end{array}$ \\
\hline Epidermal cell shape (fv) & sinuous & polygonal & polygonal & $\begin{array}{l}\text { polygonal }^{\text {ad }} \\
\text { sinuous ab }\end{array}$ \\
\hline Stomatum type & diacytic & anomocytic & anomocytic & $\begin{array}{l}\text { anomocytic } \\
\text { tetracytic }\end{array}$ \\
\hline Stomatum occurrence & $\mathrm{ad} / \mathrm{ab}$ & $\mathrm{ad} / \mathrm{ab}$ & $\mathrm{ab}$ & $\mathrm{ad} / \mathrm{ab}$ \\
\hline Trichome type & $\begin{array}{l}\text { capitate gt } \\
\text { peltate gt } \\
\text { ngt }\end{array}$ & $\begin{array}{l}\text { capitate gt } \\
\text { peltate gt } \\
\text { ngt }\end{array}$ & stellate ngt & $\begin{array}{l}\text { capitate gt } \\
\text { T-shaped ngt }\end{array}$ \\
\hline Mesophyll & homogeneous & dorsiventral & $\begin{array}{l}\text { dorsiventral } \\
\text { hypoderm }{ }^{\text {ad }} \\
\text { secretory cells }\end{array}$ & dorsiventral \\
\hline Midrib & plain-convex & biconvex & concave-convex & biconvex \\
\hline Calcium oxalate crystals & - & rare druses & rare raphides & $\begin{array}{l}\text { druses } \\
\text { prisms }\end{array}$ \\
\hline
\end{tabular}

$\mathrm{ab}$ - abaxial surface of the epidermis, ad - adaxial surface of the epidermis, fv - front view, gt - glandular trichomes, ngt - nonglandular trichomes, $\mathrm{vb}$ - vascular bundle.

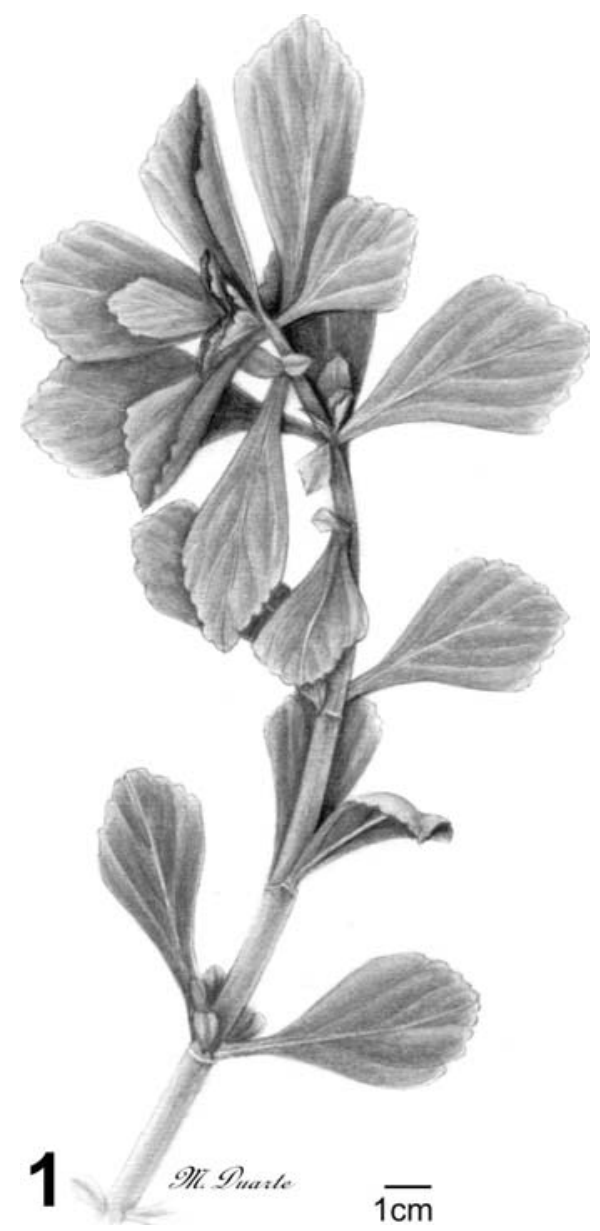

Figure 1. Plectranthus neochilus Schltr., Lamiaceae - aspect of a vegetative branch. 

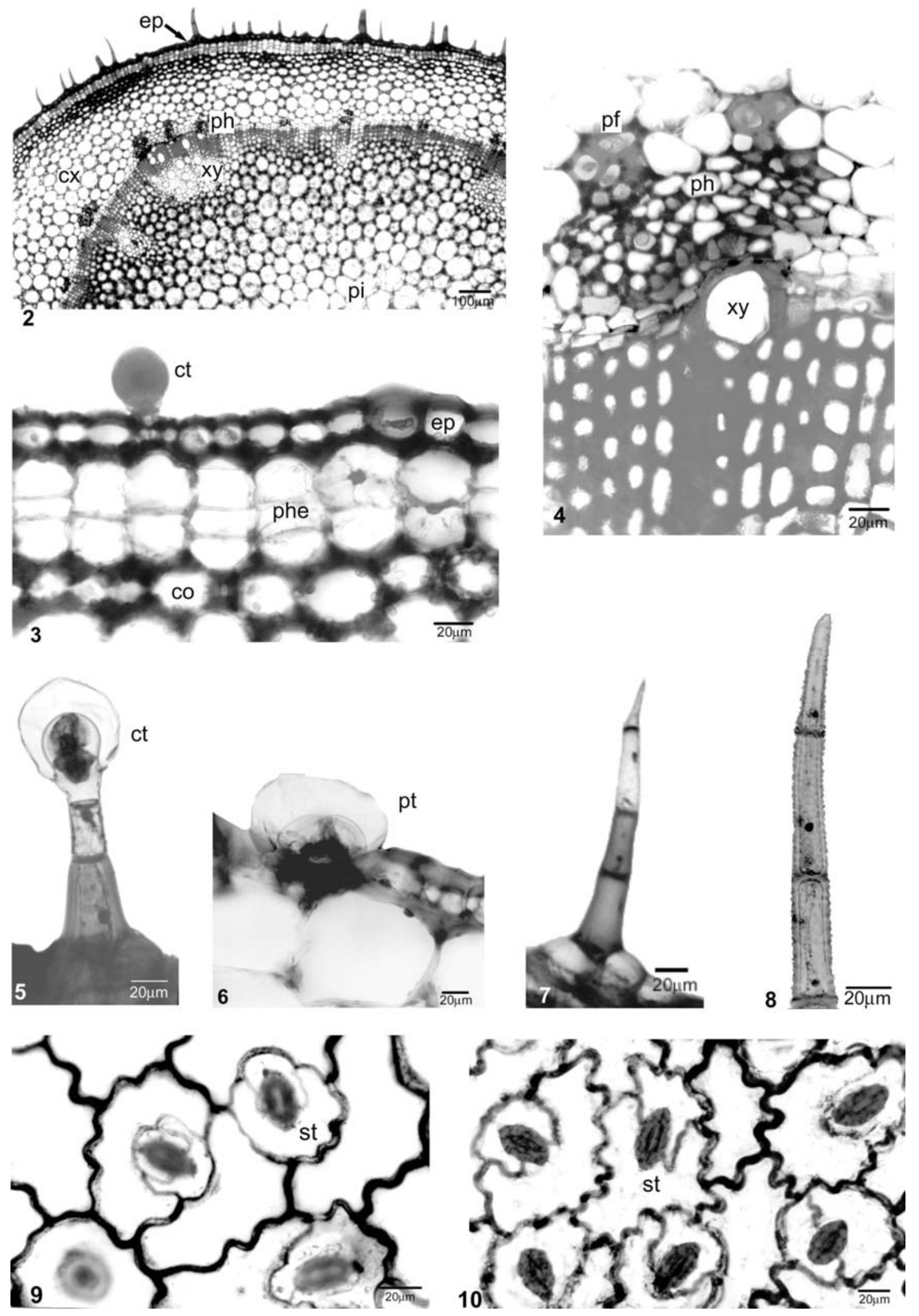

Figures 2-10. P. neochilus - 2-8 - Stem: 2 - transection of the stem in secondary growth; 3 - detail of the caulinar dermal system and collenchyma; 4 - phloem and xylem; 5 - capitate trichome; 6 - peltate trichome; 7 - non-glandular trichome; 8 - granular cuticle covering the non-glandular trichome; 9-10 - Blade - surface view of the adaxial and abaxial epidermal cells, respectively. co - collenchyma, cp - capitate trichome, cx - cortex, ep - epidermis, pf - perivascular fibers, ph - phloem, phe - phellogen, pi - pith, pt - peltate trichome, st - stomatum, $x y$ - xylem. 

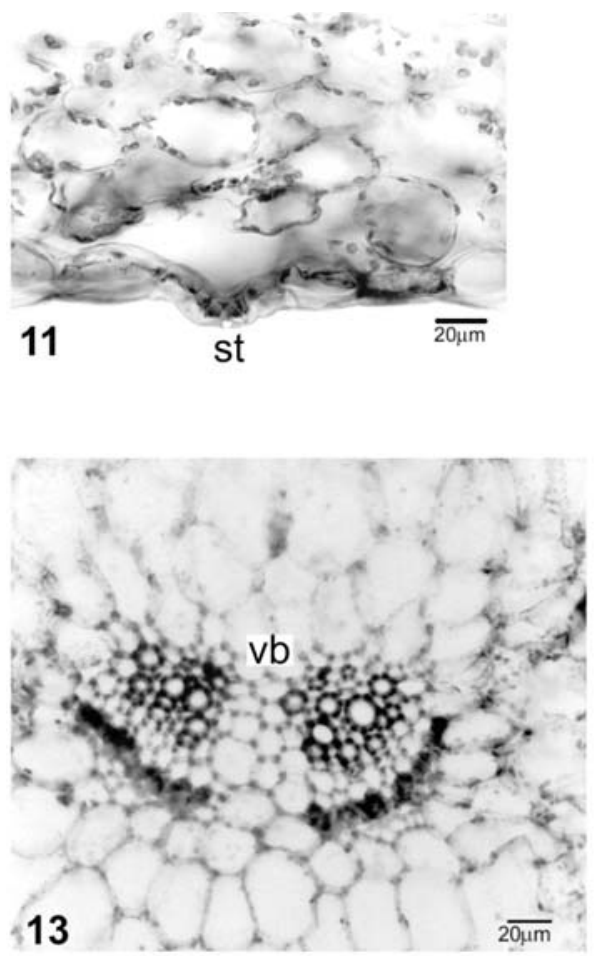
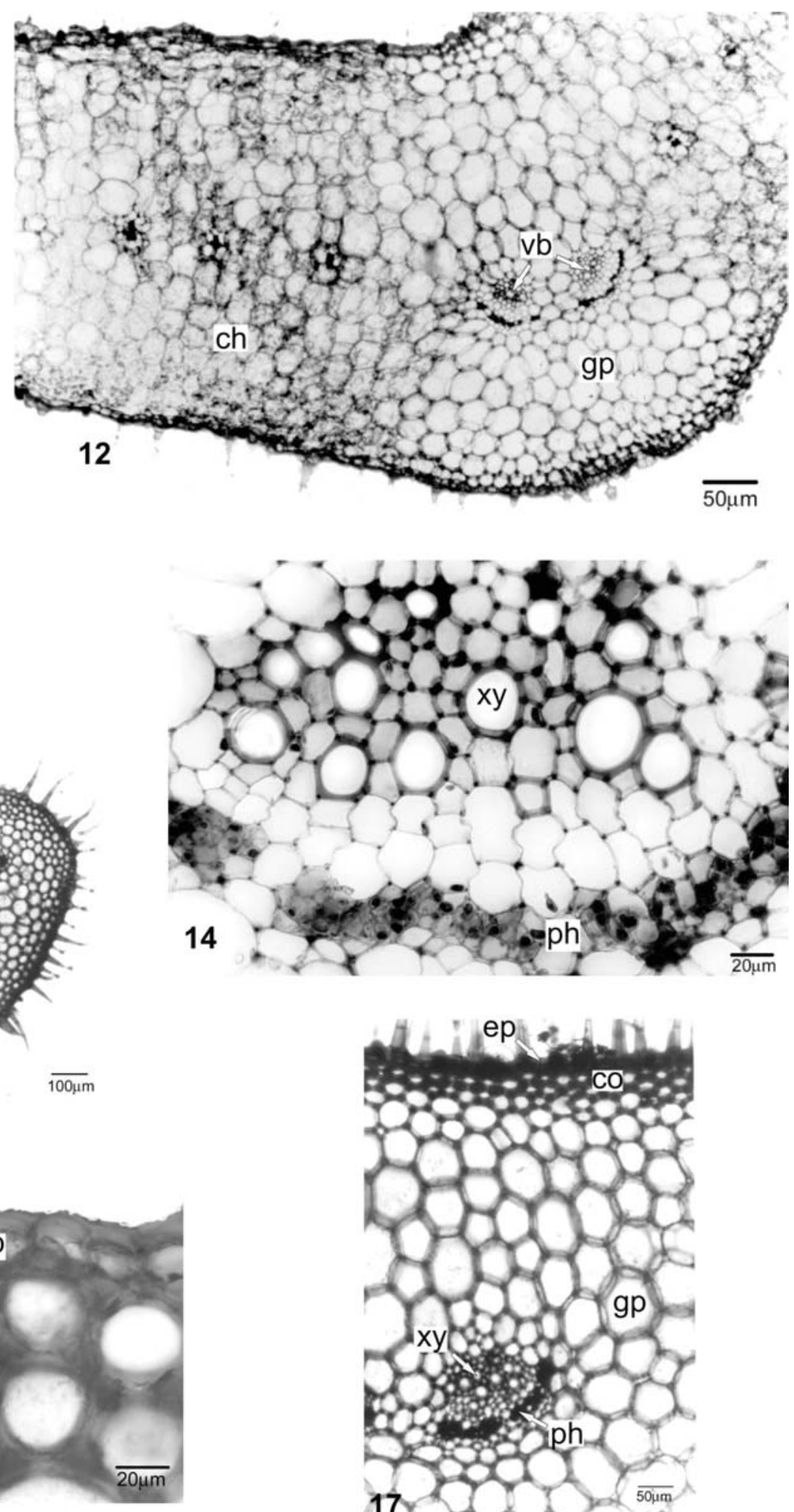

Figures 11-17. P. neochilus - Leaf: 11 - stomatum slightly above the other epidermal cells; 12 - blade and midrib in transection; 13-14 - details of the collateral bundles in the midrib; 15 - petiole transection; 16 - epidermis and collenchyma of the petiole; 17 collateral bundle embedded in the ground parenchyma. ch - chlorenchyma, co - collenchyma, ct - capitate trichome, ep - epidermis, gp - ground parenchyma, ph - phloem, st - stomatum, vb - vascular bundle, xy - xylem. 


\section{CONCLUSION}

This investigation shows that the assembled anatomical characters of $P$. neochilus contribute for this medicinal species identification. Although the stem organization of P. neochilus is similar to P. barbatus, the leaf characters are distinctive. To sum up, P. neochilus and $P$. barbatus can be distinguished since the latter has leaves with polygonal epidermal cells in surface view, anomocytic stomata, comparatively more trichomes and dorsiventral mesophyll. Besides, $P$. boldus differs form $P$. neochilus for exhibiting hypostomatic leaf, stellate trichomes, hypoderm, secretory cells and dorsiventral mesophyll. This chlorenchyma organization also occurs in $V$. condensata leaf, as well as tetracytic or anomocytic stomata, T-shaped non-glandular trichomes and calcium oxalate crystals.

\section{ACKNOWLEDGMENTS}

The authors wish to thank Gert Hatschbach from the Museu Botânico Municipal de Curitiba for the species identification, and $\mathrm{PIBIC} / \mathrm{CNPq}$.

\section{REFERENCES}

Abdel-Mogib M, Albar HA, Batterjee SM 2002. Chemistry of the genus Plectranthus. Molecules 7: 271-301.

Allemann J, Hammes PS 2003. Chemical composition of South African Plectranthus esculentus tubers. South Afr J Sci 99: 127-129.

Allemann J, Robbertse PJ, Hammes PS 2003. Organographic and anatomical evidence that the edible storage organs of Plectranthus esculentus NEBr. (Lamiaceae) are stem tubers. Field Crops Res 83: 35-39.

Ascensão L, Figueiredo AC, Barroso JG, Pedro LG, Schripsema J, Deans SG, Scheffer JJC 1998. Plectranthus madagascariensis: morphology of the glandular trichomes, essential oil composition, and its biological activity. Int J Plant Sci 159: 31-38.

Ascensão L, Mota L, Castro MM 1999. Glandular trichomes on the leaves and flowers of Plectranthus ornatus: morphology, distribution and histochemistry. Ann Bot 84: 437-447.

Barreto MA, Alves VFG, Neves LJ 1994. Contribuição ao estudo de Vernonia condensata Baker. Rev Bras Farm 75: 54-58.

Barroso GM 1991. Sistemática de angiospermas do Brasil. Viçosa: Universidade Federal de Viçosa.

Berlyn GP, Miksche JP 1976. Botanical microtechnique and cytochemistry. Ames: Iowa State University Press.

BHP - British Herbal Pharmacopeia 1996. Exeter: British Herbal Medicine Association.

Burgi C, Ruedi P 1993. Isolation and structure of long-chain alkylphenols and long-catechols from Plectranthus albidus (Labiatae). Helv Chim Acta 76: 1890-1900.

Buznego MT, Perez-Saad H 1999. Antiepileptic effect of Plectranthus amboinicus (Lour.) Spreng. (french marjoram). Rev Neurol 29: 388-389.

Cerqueira F, Silva AC, Marques CG, Simões F, Pinto MMM,
Nascimento MSJ 2004. Effect of abietane diterpenes from Plectranthus grandidentatus on $\mathrm{T}-$ and B-lymphocyte proliferation. Bioorg Med Chem 12: 217-223.

Cronquist A 1981. An integrated system of classification of flowering plants. New York: Columbia University.

Esau K 1977. Anatomy of seed plants. $2^{\text {nd }}$ ed. New York: John Wiley.

F. Bras. IV - Farmacopéia Brasileira 1996. 4.ed. São Paulo: Atheneu.

Foster AS 1949. Practical plant anatomy. $2^{\text {nd }}$ ed. Princeton: D. Van Nostrand.

Gaspar-Marques C, Rijo P, Simões MF, Duarte MA, Rodriguez B 2006. Abietanes from Plectranthus grandidentatus and $P$. hereroensis against methicillin- and vancomycin-resistant bacteria. Phytomedicine 13: 267-271.

Johansen DA 1940. Plant microtechnique. New York: McGraw Hill Book.

Juch M, Ruedi P 1997. Isolation, structure, and biological activities of long-chain catechols of Plectranthus sylvestris (Labiatae). Helv Chim Acta 80: 436-448.

Judd WS, Campbell CS, Kellogg EA, Stevens PF 1999. Plant systematics - a phylogenetic approach. Sunderland: Sinauer.

Kerntopf MR, Albuquerque RL, Machado MIL, Matos FJA, Craveiro AA 2002. Essential oils from leaves, stems and roots of Plectranthus barbatus Andr. (Labiatae) grown in Brazil. J Essent Oil Res 14: 101-102.

Liu G, Ruedi P 1996. Phyllocladanes (13-beta-kauranes) from Plectranthus ambiguus. Phytochemistry 41: 1563-1568.

Lolis MIGA, Milaneze-Gutierre MA2003. Morfo-anatomia das folhas de Vernonia condensata Baker (Asteraceae), o "figatil". Rev Bras Farmacogn 13: 68-71.

Lorenzi H, Matos FJA 2002. Plantas medicinais no Brasil nativas e exóticas. Nova Odessa: Plantarum.

Lukhoba CW, Simmonds MSJ, Paton AJ 2006. Plectranthus: a review of ethnobotanical uses. J Ethnopharmacol 103: 1-24.

Mathpal D, Mathpal R, Shah GC, Gupta RC 2002. Essential oil constituents and antifungal activity of Plectranthus japonicus K. Asian J Chem 14: 1044-1046.

Matu EN, Van Staden J 2003. Antibacterial and antiinflammatory activities of some plants used for medicinal purposes in Kenya. J Ethnopharmacol 87: 35-41.

Mauseth JD 1988. Plant anatomy. Menlo Park: Benjamin Cummings.

Mendes BG, Machado MJ, Falkenberg M 2006. Triagem de glicolipídios em plantas medicinais. Rev Bras Farmacogn 16: 568-575.

Metcalfe CR, Chalk L 1950. Anatomy of dicotyledons - leaves, stem, and wood in relation to taxonomy. Oxford: Clarendon Press.

Metcalfe CR, Chalk L 1988. Anatomy of the dicotyledons. $2^{\text {nd }}$ ed. Oxford: Clarendon Press.

Morais SM, Dantas JDP, Silva ARA, Magalhães EF 2005. Plantas medicinais usadas pelos índios Tapebas do Ceará. Rev Bras Farmacogn 15: 169-177.

Narukawa Y, Shimizu N, Shimotohno K, Takeda T 2001. Two new diterpenoids from Plectranthus nummularius Briq. Chem Pharm Bull 49: 1182-1184. 
Ngassoum MB, Jirovetz L, Buchbauer G, Fleischhacker W 2001. Investigation of essential oils of Plectranthus glandulosus Hook f. (Lamiaceae) from Cameroon. $J$ Essent Oil Res 13: 73-75.

O'Brien TF, Feder N, McCully ME 1964. Polychromatic staining of plant cell walls by toluidine blue $\mathrm{O}$. Protoplasma 59: 368-373.

Oliveira FQ, Gobira B, Guimarães C, Batista J, Barreto M, Souza M 2007a. Espécies vegetais indicadas na odontologia. Rev Bras Farmacogn 17: 466-476.

Oliveira RAG, Lima EO, Souza EL, Vieira WL, Freire KRL, Trajano VN, Lima IO, Silva-Filho RN 2007b. Interference of Plectranthus amboinicus (Lour.) Spreng essential oil on the anti-Candida activity of some clinically used antifungals. Rev Bras Farmacogn 17: 186-190.

Pereira RC, Oliveira MTR, Lemos GCS 2004. Plantas utilizadas como medicinais no município de Campos de Goytacazes - RJ. Rev Bras Farmacogn 14 (Supl. 1): $37-40$.

Ph. Helv. VII - Pharmacopoeia Helvetica 1991. 7.ed. Berne: Département Fédéral de l'Intérieur.

Rabe T, Van Staden J 1998. Screening of Plectranthus species for antibacterial activity. South Afr J Bot 64: 62-65.

Rijo P, Marques CG, Simões MF, Duarte A, Apreda-Ojas MD, Cano FH, Rodriguez B 2002. Neoclerodane and labdane diterpenoids from Plectranthus ornatus. $J$ Nat Prod 65: 1387-1390.

Roeser KR 1972. Die nadel der schwarzkiefer-massenprodukt und kunstwerk der natur. Mikrokosmos 61: 33-36.

Ruiz AR, Torre RA, Alonso N, Villaescusa A, Betancourt J, Vizoso A 1996. Screening of medicinal plants for induction of somatic segregation activity in Aspergillus nidulans. $J$ Ethnopharmacol 52: 123-127.

Sass JE 1951. Botanical microtechnique. $2^{\text {nd }}$ ed. Ames: Iowa State College.

Scavone O 1965. Contribuição ao estudo morfológico e anatômico de Coleus barbatus Benth., Labiatae. Rev Fac Farm Bioquím São Paulo 3: 249-270.

Silva MIG, Gondim APS, Nunes IFS, Sousa FCF 2006. Utilização de fitoterápicos nas unidades básicas de atenção à saúde da família no município de Maracanaú (CE). Rev Bras Farmacogn 16: 455-462.

Temple VJ, Ojobe TO, Onobun CE 1991. Chemical composition of livingstone potato tubers (Plectranthus esculentus). J Sci Food Agric 56: 215-217.

Tôrres AR, Oliveira RAG, Diniz MFFM, Araújo EC 2005. Estudo sobre o uso de plantas medicinais em crianças hospitalizadas da cidade de João Pessoa: riscos e benefícios. Rev Bras Farmacogn 15: 373-380.

Uawonggul N, Chaveerach A, Thammasirirak S, Arkaravichien T, Chuachan C, Daduang S 2006. Screening of plants acting against Heterometrus laoticus scorpion venom activity on fibroblast cell lysis. $J$ Ethnopharmacol 103: 201-207.

Vendruscolo GS, Rates SMK, Mentz LA 2005. Dados químicos e farmacológicos sobre as plantas utilizadas como medicinais pela comunidade do bairro Ponta Grossa, Porto Alegre, Rio Grande do Sul. Rev Bras Farmacogn 15: 361-372.

Vera R, Mondon JM, Pieribattesti JC 1993. Chemical composition of the essential oil and aqueous extract of
Plectranthus amboinicus. Planta Med 59: 182-183.

Werker E 1993. Function of essential oil secreting glandular hairs in aromatic plants of Lamiaceae: a review. Flavor Fragr J 8: 249-255.

Zollo PHA, Biyiti L, Tchoumbougnang F, Menut C, Lamaty G, Bouchet P 1998. Aromatic plants of tropical Central Africa: Part XXXII. Chemical composition and antifungal activity of thirteen essential oils from aromatic plants of Cameroon. Flavor Fragr J 13: 107-114. 